\title{
Anmeldelser
}

\section{Hugh Goddard: Den sande tro. Kristne og muslimer mellem konfrontation og sameksistens. \\ København: Forlaget Vandkunsten, 2011, 365 sider.}

Forholdet mellem muslimer og kristne, islam og kristendom har igennem historien været præget af gensidige erobringer, brutale krige, politiske modsætninger, økonomiske interesser, men også af gensidig intellektuel nysgerrighed, ønske om dialog, fælles interesser og hverdagens sameksistens. Den britiske professor i kristen-muslimske relationer Hugh Goddard skriver om disse mange aspekter af forholdet mellem kristne og muslimer ved kronologisk at udforske relationen fra den tidlige kristendoms relation til jøder, som den tids modsætningsforhold, over islams udbredelse, korstoge, mission og imperialisme til det 20 . århundredes dialogbevægelser. Det er en fortælling, som trækker på et væld af kilder, hvor Goddards primære fokus er på de tekstlige kilder skrevet af både muslimske og kristne religiøse lærde, det være sig teologer, munke, filosoffer, missionærer etc. Læsningen af disse kilder sætter Goddard i relation til samtidens samfundsmæssige kontekst, således at de religiøse fortolkninger af forholdet til 'de andre' foreslås forstået i relationen til aktuelle politiske konflikter og samfundsmæssig udvikling.

Det er symptomatisk for bogen, at det er de religiøse dialoger og uenigheder, der beskrives, og ikke muslimer og kristnes hverdagslige sameksistens. Det er religiøse tænkeres fortolkninger, der er i centrum, og ikke konflikter der udspringer af mødet mellem Vesten og islam, som det for eksempel gav sig udtryk i den danske tegningekrise i 2005-06, som blev resultatet af Jyllandspostens offentliggørelse af tolv karikaturtegninger af profeten Mohammed. Denne skelnen peger Goddard selv på i bogens sidste kapitel, som ikke hørte med i den oprindelige engelske udgave fra 2000. Kapitlet er tilføjet som en opdatering og er oprindeligt udgivet som artikel. Hvor denne skelnen måske umiddelbart giver mening i nutiden, er den slet ikke så entydig historisk set. Det skyldes først og fremmest, at de politiske ledere også ofte kunne have en rolle som religiøse ledere, som profeten Muhammed jo selv er et ganske udmærket eksempel på. Derfor kan det også være vanskeligere at gennemskue, hvad der er politisk, og hvad der er religiøst motiveret $i$ Goddards mange eksempler. Han peger til dels selv på, at dette ikke kan adskilles, men synes så alligevel delvis at gøre det i det afsluttende kapitel. Dermed kommer han også til at placere den nutidige dialog mellem kristne og muslimer som en dialog, der bedst finder sted mellem religiøst eller religionsvidenskabeligt kyndige inden for de respektive grupper.

Der er mange interessante og tankevækkende passager. Et af dem finder man i kapitel fem om middelalderen, der bl.a. beskriver det niende århundredes Spanien og begivenheder, der ifølge Goddard førte til vestens særegne negative syn på islam, som stadig er aktuelt. Den negative holdning har sit udspring i forestillinger, som De Spanske Martyrers Bevægelse formulerede i årene 850860 , mens de var underlagt islamisk styre. Selv om kristne under det islamiske styre var tålt og beskyttede, var de underprivilegerede og derudover isolerede fra resten af den kristne verden. Det gav grobund for den teologisk begrundede holdning, at islam var forløber for antikrist. Det er karakteristisk, at vestlige kristne udvikler en helt anden kritisk holdning til islam end de østlige kristne. Denne forskel kunne så underbygges ved læsningen af forskellige bibelsteder.

Selve fremstillingen er levende, fordi der konstant veksles mellem gengivelsen af lærde disputter og af deres samtidige politiske virkelighed. Bogen er oversat fra engelsk af Birgitte Rahbek til et letforståeligt og elegant dansk. Den eneste anke over for fremstillingen er, at der især i de kapitler, der beskriver den tidlige kristendom og islam anvendes en terminologi for religiøse retninger og ståsteder, hvis nuancer nok for de fleste læsere vil indebære konsultation af et religionsvidenskabeligt opslagsværk for helt at forstå.

Lise Paulsen Galal, ph.d., lektor, Institut for Kultur og Identitet, Roskilde Universitet. 